\title{
THE LEGACY OF G. WILSON KNIGHT
}

\author{
LAURENCE RAW* \\ Baskent University
}

\begin{abstract}
G. Wilson Knight (1897-1985) was one of the most influential Shakespearean critics of the mid-twentieth century. This piece surveys his work from 1930 until the early 1980s. Much affected by the First World War, he developed a style of criticism based on Christian principles of respect for other people and belief in an all-powerful God. Many of his most famous pieces (in THE WHEEL OF FIRE, for instance) argue for human insignificance in an indifferent universe. It is up to all of us as individuals to develop methods of coping with this world. Wilson Knight's ideas gained particular currency during the Second World War, when Britain's very future seemed at risk due to the threat of Nazi invasion. Although much derided for his use of transcendent languageespecially by his contemporary F. R. Leavis-Wilson Knight's ideas seem to have acquired new significance in a globalized world, where individuals fight to main their identity in a technology-driven environment.
\end{abstract}

Keywords: World War One; Shakespeare; Tragedy; Christianity; transcendence; textual readings.

I first encountered the criticism of Wilson Knight while at school at Dulwich College. We were studying King Lear, and had spent most of our classes concentrating on its tragic aspects as Lear comes to self-knowledge through suffering on the heath. Robert MacDowell, our educator, gave us a copy of "King Lear and the Comedy of the Grotesque," a well-known piece from The Wheel of Fire (1930), and invited discussion. I was incensed by the title and the subject-matter; how could any literary critic of standing think that King Lear was in any way funny? I responded by creating a parodic cast-list with all the major roles undertaken by leading comic performers of the late Seventies: Peter Sellers as Clouseau as Lear, Eric Sykes and Hattie Jacques as Albany and

\footnotetext{
*1_rawjalaurence@yahoo.com
} 
Goneril, Sidney James as Edmund, and Kenneth Williams as the Fool. Needless to say MacDowell was not best pleased with my efforts, and urged me to become a little more sympathetic towards Wilson Knight's arguments. Despite his eminence as an academic and an Old Boy of the school, Wilson Knight was considered something of an eccentric: at a performance as Caliban marking the opening of the Edward Alleyn Theatre in 1981, the eighty-four-year-old professor stripped naked, much to the consternation of the invited audience (Piggott 313).

Yet his work steadfastly resists any consignment to academic oblivion. The Routledge website has at least six of his books in print (Lord Byron's Marriage, Shakespearian Production, Shakespearean Tempest, The Crown of Life, The Imperial Theme, and The Wheel of Fire), not to mention a link to the Collected Works (running to 4008 pages), currently out of print. The thematic aspects of his work have been recently reviewed by Michael Taylor in Great Shakespeareans Vol. 13 (58-91). Nearly forty years after having encountered him for the first time, I find many of his arguments extremely suggestive in determining my relationship to the Shakespearean text. This article embarks on a biographical quest to discover why. It is divided into three sections: the first examines how his theories of Shakespeare were inspired by childhood memories of attending professional performances in London, as well as the desire to carve out a new career in the wake of the First World War. Wilson Knight records his excitement at attending a Shakespeare production in a lyric "On Returning from a Performance of Shakespeare's A Midsummer Night's Dream," written in 1923 but not published until 1968: "O whisper through the ages/ These secrets of the moon .../ Drunk on dark pilgrimages/ I drift in swoon" ("On Returning" 51). He spent much of the Twenties teaching at a variety of secondary schools, while establishing himself as a scholar. Through a series of lyrics he further explored some of the areas that became essential of his critical work. In "Tragedy and Romance" he looked at how great works such as Othello and King Lear transcended tragedy and comedy and aspired to spiritual issues ("Reaching to God through agony and sin/ Flames from the soul divine intensity") ("Tragedy and Romance" 55). Walking through the head teacher's garden at Dean Close School, Gloucestershire after a performance of As You Like It, he experiences "stirrings of a hidden joy" that Shakespeare has given him the opportunity to savor the ethereal ("After the Play" 52). Such musings reveal the interplay between interpretative and imaginative modes of writing that distinguished Wilson Knight's writing career.

With the appearance of Myth and Miracle (1929) Wilson Knight set forth his theories based on interpretation-i.e. responding emotionally to the text - rather than the rational act of criticism. These notions were developed at greater length in The Wheel of Fire and The Imperial Theme. I subsequently review Wilson Knight's move into full-time academia at the University of 
Toronto as he established himself as a critical force to be reckoned with. Returning to London full-time at the outbreak of World War Two, he went to work full-time at Stowe School, north of London, while assuming the role of a public intellectual by performing on the West End stage as well as writing propaganda urging readers to treat Shakespeare imaginatively as a symbol of national and global unity. The final section concentrates on his postwar career at the University of Leeds (whom he joined as a Reader in 1946 and remained till his retirement in 1962) and beyond; his writings became progressively more religious in tone, while his critical perspective shifted to other authors, notably Byron and Pope. Yet his basic preoccupations remained much the same as they had been three decades previously; he wanted to explore literature's potential to induce states of being similar to religious contemplation. Some of his claims might have seemed far-fetched, but he was a firm advocate of literature's transhistoricity: "history"-understood as the arbitrary division of time into discrete periods did not matter, as Shakespeare and Byron possess an equal power to inspire readers of all socio-economic backgrounds. What set Wilson Knight apart from his contemporaries was his belief in poetry (and Shakespeare in particular) as something to be absorbed emotionally. The meaning of individual words is of secondary importance; what matters is that we enact forms of self-reflection foregrounding the intimate and inextricable connections between our own life experiences and the act of reading Shakespeare. I argue that Wilson Knight's theories adumbrate contemporary research of a similar nature ("mesearch"), which helps to determine where we are, who we are, and where we would like to be in the future. It is this quality above all that renders him enduringly significant.

From 1909 to 1914 Wilson Knight attended Dulwich College. His school records indicate that he was an academically gifted learner but found the atmosphere oppressive. Being not good at games, he did not fit in with the largely sport-focused culture prevailing at that time. ${ }^{1}$ He turned instead to the life of the mind rather than the body: whenever possible he would go to see Shakespeare performed in London's West End. Sir Herbert Beerbohm Tree's revivals proved especially amenable due to their color, costume, and special effects. Wilson Knight also saw Granville Barker's productions at the Savoy Theatre-The Winter's Tale, Twelfth Night, and A Midsummer Night's Dreamand enjoyed the delicacy of presentation as well as the characterizations of leading actor Henry Ainley (Van Domelen 15).

During World War One Wilson Knight experienced an uneventful time in Mesopotamia and India. Although carrying out his duties successfully, he found himself as much on the margins as he had been at school; it was difficult

\footnotetext{
${ }^{1}$ I am indebted to the Keeper of the Archives at Dulwich College, Calista Lucy, for this information.
} 
for him to share confidences with his fellow-soldiers (Van Domelen 18). Returning to England in 1920 he encountered a series of personal disasters that put paid to any dreams of carving out a career in business, as his parents had expected. Not only had his wife Caroline left him, but all his investments had collapsed, rendering him bankrupt. The only way to make something of his future was to take a safe job such as secondary school teaching, a profession he pursued from 1923 until 1931. By all accounts he was popular with learners, revealing a particular enthusiasm for his work, even though he kept himself to himself outside the classroom. More importantly, the pedagogic life gave him the time and space to develop his theories of literature, which were designed to recreate the kind of emotional pleasures that he had experienced at Beerbohm Tree and Granville Barker's Shakespearean productions.

The first fruits of his intellectual labor were published in Myth and Miracle (1929), a short (32-page) essay, the first of what the author asserted would be "many papers on the various plays and themes of the Shakespeare progress" (5). He boldly claims that "art is an extroverted expression of the creative imagination which, when introverted, becomes religion" (22). The artist, in the process of creative development, "may be forced beyond the phenomena of actuality into the world of the spirit which scarcely lends itself to a purely artistic, and therefore objective, vision" (22). A good example can be seen in The Tempest, "the most perfect work of art and the most crystal act of mystic vision in our literature" (29). Regarding the Shakespearean canon as a whole, Wilson Knight subdivided it into three categories, the first being "problem plays" such as the histories, that examine the conflict between the evil and the spiritual. $^{2}$ The major tragedies comprise the second group where such conflicts are largely resolved; while the third group (the late plays) depict the tragic muse being transformed into immortality, ${ }^{3}$ with The Tempest being the best example (22-3). To share that state of grace readers (and playgoers) should set aside worldly cares and embrace the world of the spirit. Published a year later, The Wheel of Fire develops these ideas into a fully-fledged theory of literary appreciation. Poetic creation evolves naturally out of a union between "earth" and "heaven," the material and the spiritual. Entering the world of a play like The Tempest requires us to submit with "utmost passivity to the poet's work" (7). Peripheral concerns, such as speculating on the artist's intentions or investigating sources, divert us from the essentials of the text ("Shakespeare Interpretation" 6). Moreover we have no need to speculate on character, as the dramatis personae inhabit an idiosyncratic world with behavioral and emotional responses totally different from our own. To believe otherwise implies that the

\footnotetext{
${ }^{2}$ Wilson Knight's use of the term should not be confused with E. M. W. Tillyard's more widely-known work Shakespeare's Problem Plays that appeared in 1951.

${ }^{3}$ Wilson Knight deliberately omits the comedies from his model.
} 
text is an everyday cultural production bereft of imaginative power. Wilson Knight encourages us to disregard traditional models of literary analysis (primarily concentrating on formal issues), and develop instead an interpretive mode of appreciation where symbols and metaphors are approached on their own terms, not as verbal representations of everyday life ("Shakespearean Interpretation" 15).

Wilson Knight exemplifies his ideas throughout the subsequent chapters. "King Lear and the Comedy of the Grotesque" combines moments of extreme tragedy and grotesque comedy in a "playground of madness": "The core of the play is an absurdity, an indignity, an incongruity. In no tragedy of Shakespeare does incident and dialogue so recklessly and miraculously walk the tight-rope of our pity over the depths of bathos and absurdity." ("King Lear" 168). When I voiced my objections to the essay all those years ago, I was approaching it from a binarist perspective based on the assumption that "tragedy" and "comedy" should be readily distinguishable. Wilson Knight argues that in Shakespeare's poetic world the two are inseparable and should be treated as such: "the whole tragedy witnesses a sense of humour in 'the gods' which is in similar bad taste" (169). In "The Othello Music" Wilson Knight spends considerable attention on the protagonist's soliloquies, "highly coloured, rich in sound and phrase, stately. Each word solidifies as it takes its place in the pattern" (104). Othello's speeches reflect "not a soldier's language, but the quality of soldiership in all its glamour of romantic adventure; [...] [they] hold an imaginative realism [...] a certain exotic beauty, [...] a storied and romantic treasure-house of rich, colourful experiences" (106). We are so deeply implicated in the Moor's unique world of language that we consider him as "a symbol of faith in human values of love, of war, of romance in a wide and sweeping sense" (107). Death cannot destroy the spell he casts over us; we emerge from the experience of Othello with a renewed faith in humanity's potential. In his subsequent book The Imperial Theme (1931), Wilson Knight casts Cleopatra's passing in similarly elaborate language: "[She] melts naturally into love's eternity. Therefore the poet, ascending to this point, flings out the death of Cleopatra across the page like an upward tongue of fire, and earth-bound tragedy, so long our occupation, now lifts its wings and first takes the airs of immortality" (318). By listening to the sound (as well as the sense) of Othello's or Cleopatra's rhetoric we might achieve a state of oneness where issues of good and evil, tragedy and comedy, sadness or happiness no longer assume significant.

In the autobiographical Atlantic Crossing, published after he had moved to Trinity College, Toronto as a fulltime professor (1936) Wilson Knight expands his literary theories into a philosophy of life. We should realize that the universe today is "dissolved into pitiful abstractions," and the only way to negotiate them is through the "creative understanding" of great poetry. The "imaginative architecture" of any work comprises "primary impressions of earth, 
water, air, [and] fire [....] These will be mixed freely with concretely conceived individual objects of all sorts according to the [individual's] plan, and interwoven with the poet's thinking, learning, and particular experience." Reading poetry or witnessing it delivered from the stage reminds us that "We are creatures of a physical world. Our concepts of eternity reflect the constellated skies [....] Poetic thinking [...] is the technique by which the memory-world is integrated into actuality again. It aims to recreate the actual and present that rich coinage in place of a debased factual currency" (198-9). The "rich coinage" is primarily imaginative, a consciousness - or should it be a pleasure of living in the moment. Although very different in terms of theoretical orientation, he shared with F. R. Leavis and the Scrutiny group the belief that academics were public intellectuals with a bounden duty to expose the increasingly polarized nature of western democracies and to offer possible solutions for the future. ${ }^{4}$ For Wilson Knight the solution consisted of rediscovering the links between poetry and religion as a means of refining our consciousness of our place in the world. ${ }^{5}$ As an educator he had a profound influence over the young Northrop Frye, who recalled how

he [Wilson Knight] was completely possessed by Shakespeare, and gave the impression of not knowing a Quarto from a Folio text, certainly of caring even less [...] Like most of the students of my generation, Knight's books had much the same effect on me that Chapman's Homer had on Keats, and the method indicated, of concentrating on the author's text but recreating it [imaginatively] by studying the structure of imagery and metaphor, seemed to me then, and seems to me still, the sort of thing that criticism is centrally about. (259-60)

Returning permanently to Britain at the outbreak of World War Two, Wilson Knight organized a week of readings under the umbrella title This Sceptred Isle at London's Westminster Theatre performed by himself and the elderly actor Henry Ainley, whom he had seen onstage as a boy in Granville Barker's revivals. The performance unfolded in three parts: the first, "St. George for England," opened with Faulconbridge's lines from King John, followed by John of Gaunt's "sceptred isle" oration and Henry V's "Once more unto the

\footnotetext{
${ }^{4}$ Leavis's ideas are most prominently advanced in the pamphlet Mass Civilization and Minority Culture (1930). Four years later he edited Determinations, a series of essays by his fellow Scrutiny colleagues on similar topics. Leavis's ideas are analyzed in more detail in Laurence Raw, "Mass Civilization and Minority Culture: The Work of F. R. Leavis" (2001). Academia.edu. Web. 4 Nov. 2016.

${ }^{5}$ Not surprisingly such claims were viewed skeptically by Wilson Knight's academic colleagues. Reviewing The Wheel of Fire and The Imperial Theme in 1933, Alwin Thaler criticizes the books' repetitiousness, and their use of "injudicious hyperbole and excessive symbolical, allegorical, and metaphysical speculation; also, at times, by perverse vagueness of phrase and unsmiling solemnity of manner" (120).
} 
breach" soliloquy. Part Two, "Patriotism is not Enough," was made up of extracts from Hamlet, Macbeth, and Timon of Athens. The final part, "The Royal Phoenix," began with readings from Henry VIII and concluded with Queen Elizabeth I's address to the troops prior to the Spanish Armada. The Times reported that while Wilson Knight was not "the complete actor" like Ainley, he possessed "the voice and range of one, and there was no trace of the platform manner in his expression of emotion [...] the whole unusual production firmly establishes his conception of Shakespeare as the poet of a free and virile people $[\ldots .$.$] determined to fight [\ldots]$ and to take up arms against tyranny and lust for power by others" (6).

Wilson Knight's production continued a theatrical initiative pioneered by actor-manager Donald Wolfit of offering one hour-long lunchtime Shakespeare recitals for the beleagured citizens of London's West End. When Wolfit began late in 1940 there was no other entertainment on offer, as all other theaters had been closed due to the Blitz. Wolfit bravely continued (even though the Strand Theatre had been partially destroyed by a bomb), and at length audiences increased, attracted by the unusual prospect of eating ham sandwiches with their Shakespeare (Raw, Theatre 33). ${ }^{6}$ By July 1941 life had marginally improved, with most of the theaters reopening: with too many alternative attractions on offer, This Sceptred Isle lost money. Nonetheless Wilson Knight benefited from the support of his mother and brother.

In his published journalism Wilson Knight reorients his theory of literary appreciation to the patriotic cause. Published shortly before This Sceptred Isle opened, "Britain as a Dramatic Artist" draws a distinction between the British Empire which remains "gradual and obtrusive, subtly organic" dedicated to "some vast good" compared to its Teutonic adversaries. That commitment is "both so large and strange so as to seem miraculous and therefore a natural rather than a human accomplishment." Everyone in the Empire pledges loyalty to the Crown, a mystic symbol "rising, dome-like, over those harsher energies it at once nurtures and dominates." One of the ideal methods of promoting loyalty is through English poetry whose best exponents have continued a tradition of "good-hearted humanity [....] their visionary impulses [tempered] by a stern, tough reasonableness" ("Britain as Dramatic Artist"). In the pre-war era Wilson Knight had dealt mostly with universals: poetry could benefit anyone regardless of race, gender or nationality. Now he celebrates the strength of the Empire, its inhabitants and its poets as they work towards "some vast good" in the face of tyranny. Such statements do not signal any fundamental change in Wilson Knight's theoretical position. Far from it: he urges his readers

\footnotetext{
6 In an unpublished essay "A Royal Propaganda" (1956) now in the Donald Wolfit Papers at the Harry Ransom Center at the University of Texas, Wilson Knight acknowledged his debt to Wolfit (Raw, Theatre 36).
} 
to draw inspiration from poetry as a means of increasing spiritual awareness as well as promoting loyalty to the Empire. Great poetry is at heart transhistorical; its "visionary impulses" resonate for readers of all backgrounds across the centuries, ensuring that "good-hearted humanity" has a future as well as a past and present. Wilson Knight develops this idea in The Olive and the Sword, published in 1944, even though the bulk of the text had been completed three years previously. Shakespeare represents the supreme poet of transhistorical British values such as decency and spirituality, even while admitting that some of his readers might not agree:

Neither the works of Shakespeare, nor our Britannia and Saint George symbolisms, need necessarily possess those meanings I attribute to them [...] Poetic perception, like religious faith, is no passive acquiescence, but rather an active cooperation, the very truth concerned being dynamic and needing, as does the actor's art, a lively response for its realization. (100)

The freedom to disagree not only separates the British from their enemies but cultivates an enhanced appreciation of poetic thinking.

Wilson Knight continued his duties as a public intellectual, with activities encompassing giving readings on Shakespeare for the BBC Home Service and offering guest lectures to public and private societies. He returned to school teaching with a five-year stint from 1941 to 1946 at Stowe in Buckinghamshire, situated some seventy miles north of London. The transition from a university environment proved intellectually as well as mentally fruitful as he spent less time with individual learners and more on contemplating once more the relationship between the self, literature, religion, and the future of the world. ${ }^{7}$ His thoughts were eventually recorded in The Dynasty of Stowe (1945), a predominantly autobiographical work that recounts in detail the experience of wandering in the school's extensive gardens and trying to make sense of their emotional effect on him. Although many of the historic eighteenth century outdoor structures created by James Gibbs, William Kent, and Capability Brown were in a dilapidated state, they could be easily picked out among the "random play of muscled hillock and valley." ${ }^{8}$ Contemplating them prompts him to speculate on humanity's future with himself placed at the emotional center. Everyone, should be able to share his experience of encountering "pagan wisdom": it is necessary for the future of Christianity: "it must die; and only in so far as it is so refreshed will it be understood." "Christianity is itself the

\footnotetext{
${ }^{7}$ As an educator Wilson Knight was liked by fellow staff-members and learners for his kindness, enthusiasm and innocence, as well as a capacity to stimulate fruitful discussions on literature (Van Domelen 85).

${ }^{8}$ Stowe House was sold in 1922 and re-opened as a school. The gardens remain open to the public, while organized tours of the house take place during the vacations.
} 
religion of bodily life," the inspiration for "the whole of Renaissance art and thought culminating in Neitzsche [sic] [....] [that] is to be lifted into the new and greater Christianity as yet unknown." It is his responsibility to contribute to that process by writing and teaching great literature in "the guise of drama, blending antagonisms to make a new Truth, the way of expression into other dimensions through a body light to freedom and radiating power" (123-4). What distinguishes this theory from Wilson Knight's earlier work is a renewed concentration on self: an afternoon spent in the gardens leads to ontological speculation on the best way to forge a "a new and greater Christianity" in the wake of World War Two. Materialism counts for naught as he devotes himself once more to dissminating poetic thinking through literary appreciation.

Some of his claims are difficult to accept. Renewing faith only occasionally depends on encounters with objects of pagan wisdom; we experience such moments anytime, anywhere. For contemporary readers Wilson Knight's invocation of Nietzsche proved especially dubious, especially when it became known that Mussolini was an avid reader of his work. ${ }^{9}$ Yet beneath the elevated rhetoric we can appreciate Wilson Knight's efforts to forge a theory of literary appreciation based on what we might now term mesearch, with himself at the center both as subject and interpreter. He cannot describe in detail how the monuments affect him, but nonetheless uses autobiography to re-emphasize literature's (specifically poetry's) spiritual significance. ${ }^{10}$

Wilson Knight offered a variation on this theory in another essay on The Tempest appearing in The Crown of Life, published in 1947 but written in 1944 while he was still at Stowe ("Preface" vi). The play emphasizes the importance of "man's spontaneous imagination," whose "inner discipline" possesses the power to expunge the world of tyranny. Prospero's art is both "pietistic and naturalistic, as naturalistic as Christ's [....]. He is a god-man, or perhaps the godin-man, causing yet negating tragedy for his purpose as he draws man [through imagination] towards vision despite inertia and retrogression." This transhistorical journey will be "nothing like we have ever experienced, in science, in music and in poetry," penetrating "the intellect of Bacon, of Newton and of Einstein; and the other majority of art, of Bach and Beethoven, of Shakespeare himself and of Goethe" (242-3). Some of Wilson Knight's long-

\footnotetext{
${ }^{9}$ The Nazis were also familiar with Nietzsche, but there is little evidence to show that Hitler read him, even though he used selected quotations in his speeches and other pronouncements. (Trevor-Roper vi)

${ }^{10}$ It is likely that Wilson Knight was inspired by other poets who has written on the subject, especially in view of his belief in the transhistoricity of literature. In the "Epistle to Burlington" (1731), Alexander Pope pays tribute to the "Spontaneous beauties"flowers and monuments" that "slide into a whole," creating "A work to wonder atperhaps a STOWE" (66-70).
} 
established strategies characteristic of an interpretive mode of reading reemerge; the plot of The Tempest counts less than its spiritual power; understanding Prospero's central role in promoting the spiritual life takes precedence over his immediate motivations. Wilson Knight's identificaton of Prospero as a god-in-man suggests that he is within us all; by implication, then, every one of us should move towards apotheosis as the action unfolds. We cannot make sense of the journey (as it is "nothing like we have ever experienced"), but we understand perfectly well how we are given privileged access to pagan wisdom as a means to guarantee Christianity's future.

Despite his palpable conviction, most reviewers rejected his basic premises. The $T L S$ complained that "the detailed analyses by which the general thesis is sustained are often unconvincing [....] the desire to make the play fit the thesis seems to have deflected the interpretation" ("Shakespeare's Final Plays"). F. T. Prince believed that despite its "repetition of details, citations of words, phrases and images, [the book] cannot in fact conceal the underlying vagueness of [...] thought [...] Mr. Wilson Knight uses his undoubted gift of the imagination at the expense of other qualities, without which it [The Crown of Life] loses most of its value" (251-2). Those "other qualities" include textual rigor, which was considered an essential component of good criticism. Compared to critics such as Leavis, Wilson Knight's theories seemed suspect, as they allowed aesthetic concerns to overwhelm reason. The gulf between the two was palpable, as witnessed through Leavis's typically trenchant beginning to The Great Tradition, first published in 1948:

Critics have found me narrow, and I have no doubt that my opening proposition, whatever I may say to explain and justify it, will be adduced in reinforcement of their strictures. It passes as fact (in spite of the printed evidence) that I pronounce Milton negligible, dismiss the Romantics, and hold that, since Donne, there is no poet we need bother about except Hopkins and Eliot. (1)

He not only dislikes some of Wilson Knight's favorite authors, but he pours scorn on aesthetically minded critics who assume without justification that novels such as Emma can only be evaluated through "'beauty of composition,' and can give no adequate reason for the view that Emma is a great novel and no intelligent account of its perfection of form" (8). ${ }^{11}$

\footnotetext{
${ }^{11}$ Despite their diametrically opposing views, there was more in common between the two critics than we might assume. Both enjoyed working closely with learners, creating a collaborative approach to literature designed to deepen perception and increase awareness of the subject's importance to society's future. Leavis was primarily focused on material and intellectual concerns, while Wilson Knight favored the spiritual.
} 
Wilson Knight became increasingly marginalized - to such an extent, in fact, that he was moved to pen a letter to Scrutiny in December 1949: "For some years I have been aware of a slight diffidence, a reserve, in certain quarters in regard to the placing of my Shakespeare investigations in the contemporary context [....]. I have been told that references to my own work are sometimes avoided in academic and critical circles for reasons of "policy" ("Letter" 323, 326). It is possible that Leavis understood Wilson Knight's predicament: in a private communication to his brother Wilson Knight recalled meeting Leavis at Downing College Cambridge and being told that Leavis had had to fight to get the letter included in the issue on pain of resignation (qtd. in Van Domelen 132).

Now safely ensconced at the University of Leeds, which he joined as a Reader in 1946, receiving a full professorship a decade later, Wilson Knight responded by publishing two books-Lord Byron: Christian Virtues (1952), and Alexander Pope: Laureate of Peace (1955) - that further investigated the transhistorical qualities of canonical literature. In Lord Byron he reimagined Byron as a Prospero-like figure whose death represents a moment of "spatial analysis" wherein "revolution and authority, Church and State, God and Caesar, tradition and prophecy, converged; the Sermon on the Mount was all but reworked on the battlefield where Byron fought on the Greek side against the Ottomans. The imaginative unity of that experience cannot be thought; it can be lived, or dramatized. "It has been lived once only and dramatized once only, and both by Byron" (218). Byron follows Shakespeare in being able to touch "a supreme virtue rich in power and magic" (285). ${ }^{12}$ Past and present readers can draw inspiration from their example. A century earlier Pope unites beliefs of different centuries, as his work links the New Testament, the Renaissance, and the Augustan age: "superficial differences [between them] should not prevent our recognizing the Shakespearean affinities of Pope's first period in subject, emotional sympathy, and general control" (39). The Dunciad is Pope's Inferno, his Macbeth combining the religious, the cosmic, and the prophetic (69). Wilson Knight appears to revert to a theoretical position characteristic of the The Olive and the Sword as he omits some of the personally oriented aspects of literary appreciation: neither Bryon nor Pope are god-in-men. On the other hand he invokes the Nietzschean übermensch in his account of Byron's death, assuming (rightly, as it turned out) that the German philosopher's reputation among British readers had improved. Both books rework familiar arguments such as the connection between literature and religion, and the quasi-religious power of the canonical text. While justifying transhistoricity as the only imaginatively coherent mode of reading literature, Wilson Knight takes a swipe at the established critical practice of source-hunting with a vehemence not seen since The Wheel of Fire: "it has always seemed to be strange and sad that the

\footnotetext{
${ }^{12}$ A second work on Byron, Lord Byron's Marriage, appeared five years later.
} 
treatment of literature as rooting backwards into sources and causes should in every age be academically honourable, while any attempt to establish contact with its forward pointings is considered the preserve only of amateurs and cranks" (Pope viii).

Reaction to both books from mainstream journals was both lukewarm and in some cases overtly patronizing. The $T L S$ dismissed his notion of "spatial analysis" as a reworking of familiar material: "[the process] involves taking incidents from their context to regroup them under attributes or aspects of the central figure [under discussion]" ("A Napoleonic Byron"). The same journal expressed disappointment with the Pope book that left readers "stumbling along by the side of a man who obviously cares deeply for poetry, but whose powers of expression often seem to be inadequate to his vision, or is seeing something that does not appear to be there at all" ("Pope Re-Examined"). By 1955 the journal expressed more general disquiet with what they saw as Wilson Knight's magpie-like habit of cherry-picking "some attitudes [expressed by other literary authorities] and [...] [applying] them, with far less historical propriety, to Shakespeare." A distressingly large proportion of his considerable output comprised a mélange of "literary parallels and analogies of doubtful validity" that should be deemed eccentric and 'unsafe'." More damagingly he remained stubbornly reluctant to quote the critical insights of his peers, whose careful exegeses possessed "something of the attribute and much of the specialization of the surgeon" ("Shakespearean Critic").

At this historical distance it is difficult to understand why Wilson Knight's oeuvre should have generated such extreme reactions, however radically his theories diverged from those of the critical mainstream. Perhaps many of his colleagues were secretly jealous of his success: since the outbreak of World War Two he had been recognized as something of a literary celebrity, regularly in demand as a broadcaster, lecturer and (latterly) drama director. Read by academic and general readers alike (as the $T L S$ acerbically noted) ("Shakespearean Critic"), he was treated as a maverick within the literary critical fraternity who could readily subvert accepted models of textual analysis. ${ }^{13}$ In truth such intentions were completely foreign to an academic who spent most of his time teaching, directing and advising learners. Although superficially pleasant to his colleagues, he disliked public gatherings, and preferred to have as much time on his own to write. Reticent as well as conservative in outlook, he took pains to treat everyone with equal fairness, even his critical enemies. Academic and critical in-fighting were of no interest to him (Van Domelen 135).

13 F.R. Leavis experienced similar treatment from his Cambridge colleagues. An obituarist claimed this was mostly due his to his reputation as well as his popularity as an educator (Ezard). 
Although retiring in 1962 and devoting the remainder of his lengthy life (he died in 1985) to writing about Shakespeare, Pope, and other favorite authors, the passage of time proved unkind to him. In 2009 Erin Minear went so far as to accuse "The Othello Music" of generating "an interpretive crisis in which the play's own language and the way it communicates meaning and events to an audience are implicated" (355-6). He overlooked basic historical facts of the Renaissance that showed how "the relationship between the music of the spheres and the audible earthly voice of music of voices and instruments was considerably more problematic" (356). The implication is clear: Wilson Knight had rehearsed his familiar critical strategy of developing arguments without referring to previous research on the topic.

If Wilson Knight is as unreliable as she claims, why should Robert MacDowell give us "King Lear and the Comedy of the Grotesque" to read at Dulwich, especially as we were just starting out as learners of Shakespeare? The answer lies in the desire to provoke rather than accept and thereby cultivate what Wilson Knight himself called "active cooperation" (Olive and Sword 100). MacDowell knew that some of us would disagree with Wilson Knight's thesis, but through that process of dissent we would come to realize that there was no such thing as an "accepted" interpretation of a Shakespearean text; we had to forge our own views. This might not seem an especially original conclusionaren't all learners of Shakespeare supposed to do the same? Yet if we reconsider Wilson Knight's oeuvre in the light of that statement we might shed further light on his transhistorical legacy.

His decision to become a literary scholar while school-teaching in the Twenties was deliberate, an attempt to make sense of his personal relationships to canonical texts. Although making few, if any direct references to himself in his early work-at least until Atlantic Crossing. Myth and Miracle and The Wheel of Fire show him engaged in an ongoing process of what contemporary scholars have termed mesearch, using Shakespeare to explore his relationship to Christianity and literature (and thereby justify his choice of métier). Emma Rees offers some suggestive definitions of the term: mesearch deconstructs academic master narratives; rather than exploring texts, it looks at how all forms of research inscribe themselves within us; and thereby illuminates the connections between life-experience and academic research. Mesearchers often have an enhanced sense of self-awareness, even if their agenda might not be recognized by their peers. Through their efforts "profound silences and erasures in the academy" can be uncovered - specifically the intimate connection between teaching, research and the self (Rees). Wilson Knight spent much of his career in challenging master narratives - witness his call for an interpretive rather than a formalist mode of literary appreciation with the emphasis placed on selfdiscovery of poetry's unique qualities and their relationship to Christianity. Wilson Knight had already accomplished that process; his essays in Myth and 
Miracle and The Wheel of Fire asked readers to follow his example. His theories posit academic critics not as authority-figures dictating matters of taste but cheerleaders inviting us to share their enthusiasms. Such radical views predictably incensed his colleagues. The American scholar R. W. Babcock dismissed his work as superficial: "Has the critic picked up more than he admits from previous criticism, and does his system interpret the Elizabethan Shakespeare anyway? [...] it is an extremely unfortunate development in the history of Shakespearean criticism that such a conspicuously visionary and selfsatisfied romantic as Mr. Knight should now arise" $(321,329)$. The term "selfsatisfied" is significant: whereas Babcock uses it pejoratively, I would argue that this was precisely what Wilson Knight aspired to by challenging prevailing critical narratives and offering a way forward for his readers. Although not turning away from texts altogether, he offered self-satisfaction for his readers through his readings of Othello and King Lear.

Separated by nine years, Atlantic Crossing and The Genius of Stowe show Wilson Knight struggling to achieve similar self-satisfaction. Both texts are essential to our understanding of his thought as he reassesses his position as a scholar while drawing on spontaneous experiences as a basis for more general ontological reflections on his place in the world and how literature helps to sustain it. The experience gave him a renewed faith in transhistoricity, where readers would view the canon in its entirety, free from the kind of irritating periodization that shaped most critical writing. To achieve this interpretive state of mind we have to reflect carefully on what literature means to us rather than accepting the predigested opinions of other critics.

Sadly Wilson Knight's theories could not open theoretical fissures within Schools of English Literature on both sides of the Atlantic. Accused of repetitiveness in the late Sixties by American Shakespearean Thomas B. Stroup (his books "follow and repeat again the well-known themes and dispositions of his numerous early works" (188)), and critical myopia by Robert Ornstein (with his arguments being full of "blindered [sic] views of the plays" (108)), it seemed as if he was doomed to critical life on the margins. Yet that marginality has given him unexpectedly posthumous power, as we continue to read his books and articles. Without conscious effort, Wilson Knight has at last forged an important space in Shakespeare criticism, learning, and teaching through his emphasis on mesearch-related interpretive activities where personal feelings matter more than scholarly apparatus, despite the fact that Wilson Knight's work is grounded in an extensive knowledge of source-texts as well as criticism past and present. In researching this article I have been alternately inspired and infuriated by Wilson Knight's prose that can become so incredibly florid as to be almost impenetrable, yet offer personal insights about my life as a Shakespearean scholar at the most unexpected moments. I'd like to think that this is the kind of "active cooperation" he would have welcomed. 


\section{Works Cited}

Babcock, R. W. "The White Knight as Critic: Mr. Wilson Knight's Criticism of Shakespeare." Sewanee Review 4.2-3 (Jul.-Sep. 1934): 312-29. Print.

Ezard, John. "Obituary: Frank Raymond Leavis." The Guardian 18 Apr. 1978. Web. 13 Nov. 2016.

Frye, Northrop. "The Search for Acceptable Words.” Daedalus 117.3 (Summer 1986): 251-72. Print.

Knight, G. Wilson. “After the Play.” 1926. Gold-Dust with other Poetry. 52-4. London: Routledge and Kegan Paul, 1968. Print.

--- Atlantic Crossing: An Autobiographical Design. Combining Autobiography, A Philosophy of Life, A Transatlantic Journey, A Love Story. London: J. M. Dent, 1936. Print.

---. "Britain as Dramatic Artist: Poets and Imperial Destiny." TLS 5 Apr. 1941. Print.

---. "The Diadem of Love: An Essay on Antony and Cleopatra." The Imperial Theme: Further Interpretations of Shakespearean Tragedies Including the Roman Plays. 263-327. 1931. ondon: Methuen, 1985. Print.

---. The Dynasty of Stowe. London: Fortune Press, 1945. Print.

---. The Imperial Theme: Further Interpretations of Shakespearean Tragedies Including the Roman Plays. 1931. London: Methuen, 1985. Print.

---. "King Lear and the Comedy of the Grotesque." The Wheel of Fire: Interpretations of Shakespearean Tragedy. 1930. 160-77. London: Methuen \& Co., 1969. Print.

---. Laureate of Peace: On the Genius of Alexander Pope. London: Routledge \& Kegan Paul, 1955. Print.

---. "Letter to the Editor." Scrutiny XVI (Dec, 1949): 323-6.

---. Lord Byron: Christian Virtues. London: Routledge \& Kegan Paul, 1952. Print.

---. Lord Byron's Marriage. London: Routledge \& Kegan Paul, 1957. Print.

---. Myth and Miracle: An Essay on the Mystic Symbolism of Shakespeare. London: J. Burrow, 1929. Print.

---. The Olive and the Sword. Oxford: Oxford University Press, 1944. Print.

---. "On Returning from a Performance of A Midsummer Night's Dream." 1923. GoldDust with other Poetry. 51. London: Routledge and Kegan Paul, 1968. Print.

---. "The Othello Music." The Wheel of Fire: Interpretations of Shakespearean Tragedy. 1930. 97-120. London: Methuen \& Co., 1969. Print.

---. "On the Principles of Shakespearean Interpretation." The Wheel of Fire: Interpretations of Shakespearean Tragedy. 1930. 1-17. London: Methuen \& Co., 1969. Print.

---. "Preface." The Crown of Life: Essays in Interpretation of Shakespeare's Final Plays. 1947. vi-vii. London: Methuen, 1985. Print.

---. "Tragedy and Romance." 1923. Gold-Dust with other Poetry. 55. London: Routledge and Kegan Paul, 1968. Print.

---. The Wheel of Fire: Interpretations of Shakespearean Tragedy. 1930. London: Methuen, 1969. Print. 
Leavis, F. R., ed. Determinations: Critical Essays. London: Chatto and Windus, 1934. Print.

---. The Great Tradition. London: Chatto and Windus, 1948. Print.

---. Mass Civilisation and Minority Culture. London: Minority Press, 1930. Print.

A Midsummer Night's Dream. Dir. Harley Granville Barker. Perf. Nigel Playfair, Baliol Holloway, Evelyn Hope. Savoy Theatre, London, 8 Dec. 1912. Theater Performance.

Minear, Erin. "Music and the Crisis of Meaning in Othello." SEL 1500-1900 49.2 (2009): 355-70. Print.

“A Napoleonic Byron.” TLS 19 Dec. 1952. Print.

Ornstein, Robert. "A Challenge Unfulfilled." Shakespeare Quarterly 29.1 (Winter 1978): 108-9. Print.

Piggott, J. R. [Jan]. Dulwich College-A History. London: Dulwich College, 2008. Print.

Pope, Alexander. "Epistle to Burlington" ("Epistles to Several Persons: Epistle IV, To Richard Boyle, Earl of Burlington"). 1731. Representative Poetry Online. University of Toronto, 2003. Web. 11 Nov. 2016.

"Pope Re-examined." TLS 31 Dec. 1954. Print.

Prince, F. T. "Reviewed Work(s): The Crown of Life by G. Wilson Knight; The Golden World of 'King Lear' by Geoffrey L. Bickersteth.” RES 24.95 (Jul, 1948): 2512. Print.

Rees, Emma. "Self-Reflective Study: The Rise of 'Mesearch." THES 19 Mar. 2015. Web. 12 Nov. 2016.

Raw, Laurence. "Mass Civilization and Minority Culture: The Work of F. R. Leavis." 2001. Academia.edu. Web. 4 Nov. 2016.

---. Theatre of the People: Donald Wolfit's Shakespeare Productions 1937-53. Lanham: Scarecrow, 2015. Print.

"Shakespearean Critic." TLS 10 May 1955. Print.

"Shakespeare's Final Plays." TLS 25 Oct. 1947. Print.

Stroup, Thomas B. "Byron and Shakespeare and Shakespeare and Religion by G. Wilson Knight.” Shakespeare Quarterly 21.2 (Spring 1970): 188-9. Print.

Taylor, Michael. "G. Wilson Knight.” Great Shakespeareans Vol. 13. Ed. Hugh Grady. 58-91. London: Bloomsbury, 2012. Print.

Thaler, Alwin. "The Wheel of Fire and The Imperial Theme." MLN 48.2 (Feb. 1933): 119-21. Print.

This Sceptred Isle. Prod. G. Wilson Knight. Perf. Wilson Knight, Henry Ainley. Westminster Theatre, 21 Jul. 1941. Theater Performance.

Tillyard, E. M. W. Shakespeare's Problem Plays. London: Chatto and Windus, 1951. Print.

Trevor-Roper, Hugh, ed. Hitler's Table Talk 1941-44. New York: Enigma. Print.

Twelfth Night. Dir. Harley Granville Barker. Perf. Arthur Wontner, Lillah McCarthy, Arthur Whitby. Savoy Theatre, London, 15 Nov. 1912. Theater Performance.

Van Domelen, John E., Tarzan of Athens: A Biographical Study of G. Wilson Knight. Bristol: Redcliffe, 1987. Print.

"Westminster Theatre: This Sceptred Isle.” The Times 23 Jul. 1941: 6. Print. 
The Winter's Tale. Dir. Harley Granville Barker. Perf. Henry Ainley, Cathleen Nesbitt, Felix Aylmer. Savoy Theatre, London, 21 Sep. 1912. Theater Performance. 